\title{
二次覆工で補強されたシールドセグメントリングの挙動について BEHAVIOR OF SHIELD SEGMENT RING REINFORCED BY SECONDARY LINING
}

\author{
村上博智* . 小泉 淳** \\ By Hirotomo MURAKAMI and Atsushi KOIZUMI
}

\begin{abstract}
This paper investigates the behavior of shield tunnels reinforced by secondary lining based on experimental results. Test models are composed of notched steel rings with mortar cast-in-place to their interiors.

Concentrated load is applied at the models which are elastically supported. Three major types of the models are experimented; the two of which are one with dowels and the other without dowels between steel and mortar rings, and that the third is a model in which bonding between outer and inner rings are increased by using resin mortar as a secondary lining. Based on the experimental results, analytic model for two-layer structures, the model for composite structures and the model for intermediate state of structures are proposed. Furthermore the study is made on the application of those analytic models to design practice of shield tunnels.

Keywords : shield tunnel, segment, secondary lining
\end{abstract}

\section{1. まえがき}

シールド工法によって構築されたシールドトンネルで は，セグメントによる一次覆工の内側に現場打ちコンク リートによる二次覆工を行う場合が多い. しかし二次覆 工はトンネルの蛇行修正, 防水, セグメントの防蝕や仕 上げ工などを目的として用いられ，トンネル覆工の主体 構造は一次覆工であるセグメントリングと考え, トンネ ルに作用する最終的な荷重に対して, それを設計するの が一般的である11.

トンネルに作用する最終的な荷重に対する経時的な変 化が明らかでない現況では, 上述の考え方は合理的と考 えられるが, 二次覆工のコンクリートが耐荷能力を発揮 できるようになった後に, 荷重が累加されたり, 除去さ れる場合や，既設のシールドトンネルに近接して新たな 構造物が構築される場合などでは, 一次覆工であるセグ メントリングと二次覆工であるコンクリートリングと は, 協力して挙動するものと考えられる. しかしながら 両覆工間の荷重分担など力の伝達機構が明確でない現状

* 正会員 早稲田大学教授 理工学部土木工学科 ( (160 新宿区大久保 3-4-1)

** 正会員 工博 東洋大学助教授 工学部土木工学科 （テ350 川越市鯨井中野台 2100）
では二次覆工を構造体として積極的に設計に取り入れる までには至っていない.

一次覆工と二次覆工との相互作用や荷重分担に関する 従来からの研究はきわめてわずかで, 次に述べる数例に 過ぎないようである.

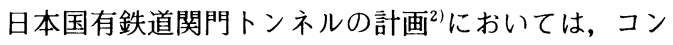
クリートで二次覆工される鋳鉄製の箱型セグメントを用 いたセグメントリングは二次覆工のコンクリートと合成 構造として挙動するものと考えてその応力計算を行って いる. また関門道路トンネルの海底部の設計汭にあたっ ては, 一次覆工のセグメントリングは土王を受け持ち, 二次覆工のコンクリートリングは水圧を受け持つという 考え方を採用している. さらにBudapest 工科大学の Széchy 教授はその著書 ${ }^{4}$ において, 一次覆工と二次覆 工をともに曲げ㓮性一様なリングと考えて, それぞれが 独立に挙動するものとして, 鉛直方向等分布荷重を受け る場合について, 両リングの水平方向直径変化量を等置 して, 両リングの分担する等分布荷重の大きさを求める 考え方を示している.

最近では二次覆工を構造体として積極的に評価しよう という動きがみられるようになり ${ }^{5)}$, この分野における 研究も少しずつ進められてきている(6) 16).

本研究は二次覆工のコンクリートライニングが耐荷能 
力を発揮できるようになった後にトンネルへ既知の荷重 が作用した場合を想定し，セグメントリングの 1 リング を対象として，一次覆工と二次覆工との相互作用を実験 的に検討し，これに理論的考察を加えるとともに，その 結果を用いて二次覆工で補強されたシールトセグメント リングの設計法を提案しようとしたものである.

\section{2. 模型セグメントリングを用いた実験}

\section{（1）実験の概要}

セグメントリングはセグメントを継手ボルトなどで連 結して構成するのが一般的である．著者らはこのような セグメント継手を曲げモーメントに対する回転ばねにモ デル化して，セグメントリングを線形回転ばねを有する 円弧部材で構成されているものと考えて，その挙動を解 析する方法 ${ }^{17)}$ を提案してきている．この場合，リングの 変形に伴って生ずる半径方向および接線方向の地盤反力 は,リングの変形が地山方向に向かう範囲にのみ発生し, その大きさは Winkler の仮定に従うものとしている.

シールドトンネルの置かれているこのような現実にな るべく忠実であるよう配慮して実験用模型セグメントリ ングを作成し，その支持方法に考慮を加えた。

Fig. 1 が実験装置の概要である. セグメントリングを 評価した鋼管は，外径 $508 \mathrm{~mm}$, 幅 $100 \mathrm{~mm}$ で厚さ 16 $\mathrm{mm}$ である.この鋼管の外側には Fig. 2 に示す切り欠き を $60^{\circ}$ 間隔に設けてセグメント継手を評価した。またこ の鋼管の内側には Fig. 3 に示す寸法のジベルを等間隔に 配置した.ジベルとして鋼板を用いた例は箱型セグメン トの縦リブを想定したものであり，ボルトを用いた例は 平板型コンクリートセグメントに用いられているジベル 筋を想定したものである. Fig. 1 は 1 リングに 6 個のジ ベルを用いた例（中心角が $60^{\circ}$ 間隔）を示してある. 1 リング当たり 18 個のシベルを用いた例では，すでに設 けたジベルを含みジベルの中心角が $20^{\circ}$ となるようジベ

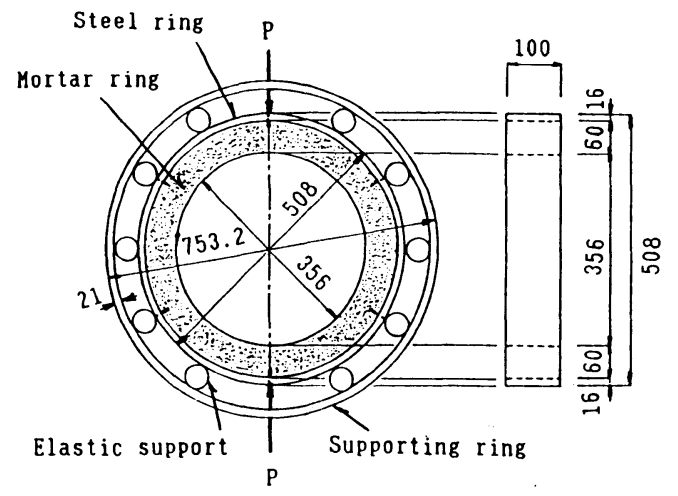

unit in $\mathrm{mm}$

Fig. 1 Set up of test model.

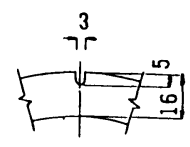

(a)

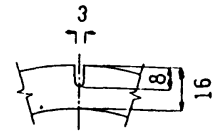

(b) unit in $\mathrm{mm}$

Fig. 2 Dimensions of U notch.
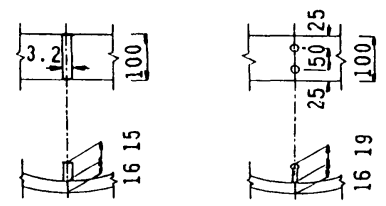

(a) Steel plate (b) Bolt (M5) unit in $\mathrm{mm}$

Fig. 3 Types and dimensions of dowel.

\section{ルを配置した。}

セグメントリングを想定した鋼管の内側には厚さ 60 $\mathrm{mm}$ のモルタルまたはレジンモルタルを打設して, 二次 覆工のコンクリートライニングを評価した。

このトンネル模型を水平架台上に設置し，リングの一 直径方向に集中荷重を載荷した.リングが変形する際に 水平架台と模型セグメントリングとの間に摩擦が生じな いように，両者の間にころを配した。

また，現実のトンネルにおける地盤反力を評価するた めFig. 1 に示す弾性支承用鋼管（外径 $101.6 \mathrm{~mm}$, 幅 $100 \mathrm{~mm}$, 厚さ $3.2 \mathrm{~mm})$ を設けた. 弾性支承用鋼管はそ の中心角が $30^{\circ}$ 間隔となるよう 10 個配置した.

さらにその外側には外径 $753.2 \mathrm{~mm}$, 幅 $100 \mathrm{~mm}$, 厚 さ $21 \mathrm{~mm}$ の支持用鋼管を設けた.

実験の種類は計 21 種, 各 2 体ずつの実験を行った。 その主なものはTable 1 に示す 5 つのタイプである.

なお，鋼製リングに設けた切り欠きの寸法は, Type 1, Type 2 および Type 3 についてはFig. 2(a)に, Type 4, Type 5 についてはFig. 2(b) にそれぞれ示すとおりで ある・

実験に用いた鋼材はSS-41 またはその相等品である. また二次覆工に用いたモルタルの配合は重量比で水：セ メント：砂の比が $1: 2: 5$ である. 一方レジンモルタル

Table 1 Types of experiment.

\begin{tabular}{|c|c|c|c|}
\hline $\begin{array}{r}\text { Dowels par } \\
\text { a ring }\end{array}$ & 0 & 6 & 18 \\
\hline $\begin{array}{c}\text { Materials of } \\
\text { 2nd lining }\end{array}$ & & & \\
\hline Mortar & Type 1 & Type 2 & Type 3 \\
\hline Resin mortar & Type 4 & & Type 5 \\
\hline
\end{tabular}


Table 2 Material properties of mortar and resin mortar.

\begin{tabular}{|c|c|c|c|l|l|}
\hline Type & $\begin{array}{r}\text { Compressive } \\
\text { strength }\end{array}$ & $\begin{array}{c}\text { Tensile } \\
\text { strength }\end{array}$ & $\begin{array}{l}\text { Bending } \\
\text { strength }\end{array}$ & Young's modulus & $\begin{array}{l}\text { Poisson's } \\
\text { ratio }\end{array}$ \\
\hline 1,3 & $429(42.1)$ & $21(2.0)$ & $62(6.1)$ & $2.5 * 10^{5}\left(2.5 * 10^{4}\right)$ & 0.22 \\
\hline 2 & $436(42.8)$ & $25(2.5)$ & $69(6.8)$ & $2.4 * 10^{5}\left(2.4 * 10^{4}\right)$ & 0.19 \\
\hline 4,5 & $261(25.6)$ & $67(6.6)$ & $157(15.4)$ & $4.1 * 10^{4}\left(4.1 * 10^{3}\right)$ & 0.28 \\
\hline
\end{tabular}

unit in $\mathrm{kgf} / \mathrm{cm}^{2}(\mathrm{MPa})$

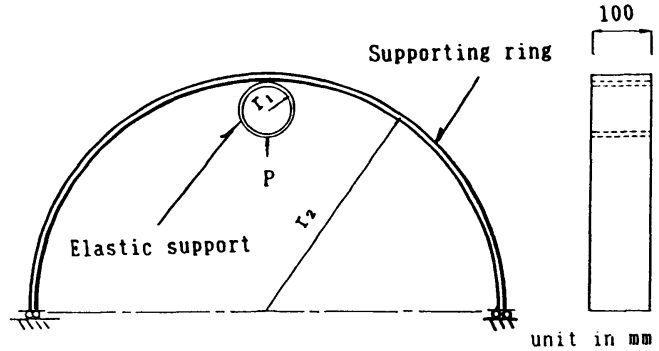

Fig. 4 Supporting system of test model.

の配合は, 結合材と接着用硅砂の重量比が $1: 5$ であり, それぞれの材料特性は Table 2 に示すとおりである.

二次覆工材としてモルタルを用いた場合, 比較的小さ い荷重でひびわれが発生したので,ひびわれ発生前の挙 動が十分把握できたか否かの不安があったため，モルタ ルより引張強度の高いレジンモルタルを二次覆工材とし た実験を追加した．しかし結論的にはその必要はなかっ たことが明らかとなった。

模型リングの挙動を解析するにあたって, 地盤の抵抗 土圧を評価する弾性支承用鋼管のば称定数 $K$ は Fig. 4 を参照すれば解析的に求められるが, 鋼管の寸法許容差 による不確実さも考えられるので, 実験結果を加味して, $K=1700 \mathrm{kgf} / \mathrm{cm}\left(1.67 \times 10^{6} \mathrm{~N} / \mathrm{m}\right)$ と定めた.

\section{(2) 測 定項目}

測定項目は Fig. 1 を参照して, 載荷の荷重方向および これに直交する方向の直径変化量と荷重方向から $10^{\circ}$, $45^{\circ}$ および $80^{\circ}$ の位置, すなわち 12 断面における鋼製り ングおよびモルタルリングの円周方向の表面ひずみであ る.

\section{3. 解析モデル}

実験結果によれば，モルタルで二次覆工された模型セ グメントリングは, 二次覆工の材料やジベルの数によっ て多少異なった挙動をする.

測定された円周方向の表面ひずみを観察すると，鋼製 リングとモルタルリングの半径方向断面内で, ひずみ分 布がその境界でくい違いを生じて，いわゆる重ねリング 構造として挙動する場合, 境界でひずみ分布が連続で平
面保持の仮定が成り立つ合成リング構造として挙動する 場合およびその中間的な挙動をする場合に分類して考え ることができる.

以下にこれら 3 つ場合の実験結果を説明する構造解 析モデルを提示する。なお，実験に用いたトンネル模型 はトンネル軸に対して対称な構造であるばかりでなく， 加えた荷重によっても対称な変形をするものと考えられ るので解析モデルはトンネルの $1 / 4$ の部分について示 す.

\section{（1）重ねリング構造と考えられる場合の解析モデル (Model 1)}

Fig. 5 は一次覆工を示す鋼製りングと二次覆工を示す モルタルリングとが重ねリング構造として挙動すると考 えられる場合のひびわれ発生前の状態を示す解析モデル である.

このモデルでは外側に示す鋼製リングの切り欠き部分 は, 曲げモーメントに対して線形回転ばねに評価してい る. また半径方向外側に付したばね $K$ は弾性支承用鋼 管の作用を示すもので，見実のシールドトンネルでは地 盤の抵抗土圧を想定したものである.したがって，この ばねは圧縮される場合のみ作用するものである.

Fig. 5 において内側のリングは二次覆エリングを示し ている.これらの両リングは図示のように半径方向ばね $k_{v}$ と接線方向ばね $k_{u}$ とで連結されていると考える. 両 リングが離間している範囲では, 両リングの力の伝達は

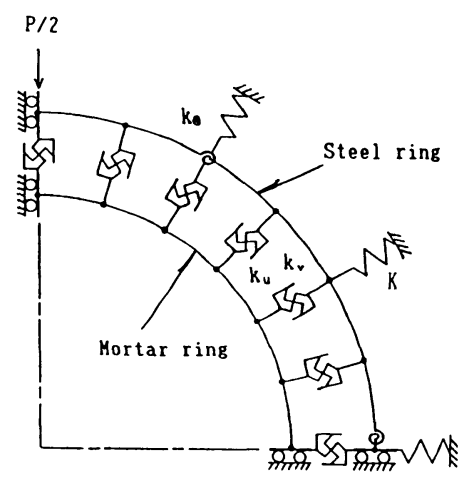

Fig. 5 Analytical model (Model 1). 
ないから $k_{u}=k_{v}=0$ とする，両リングが接する範囲で は両リングの変位は等しいと考えられるから,これらの ばね定数 $k_{u}, k_{v}$ は数値計算上, ともに無限大に近い值 を用いる.

したがって，計算を始める段階では，すべての節点に 地盤の抵抗土圧を評価するばね $K$ と, 両リングを連結 するばね $k_{u}, k_{v}$ を付しておく，計算の各段階でばねに 引張力が作用するとそのばねは取り外し，ばねの位置が 収束するまで繰返し計算を行う。

二次覆工にひびわれが発生した後の状態を評価する解 析モデルは, Fig. 5 においてひびわれの発生する位置, すなわち荷重方向の二次覆工の節点をヒンジとする以外 は，ひびわれ発生前と同一のモデルを用いる.

Fig. 5 に示す回転ばね定数 $k_{\theta}$ は正負の曲げモーメン トに対して，ほぼ等しいと考えられる．この值は解析的 な方法によって求めることも可能であるが，使用材料の 寸法許容差の影響を考慮して，実験結果を加味したうえ で定めた (Fig.6).

その結果，切欠き寸法が Fig. 2(a) の場合には， $k_{\theta}=$ $2.43 \times 10^{6} \mathrm{kgf} \cdot \mathrm{cm}\left(2.38 \times 10^{5} \mathrm{Nm}\right)$, Fig. $2(\mathrm{~b})$ の場合に ついては, $k_{\theta}=3.72 \times 10^{5} \mathrm{kgf} \cdot \mathrm{cm}\left(3.65 \times 10^{4} \mathrm{Nm}\right)$ であっ た.

（2）合成リング構造と考えられる場合の構造モデル (Model 2, Model 3)

Fig. 7 は一次覆工と二次覆工とが全円にわたって合成 リング構造として挙動すると考えられる場合のひびわれ

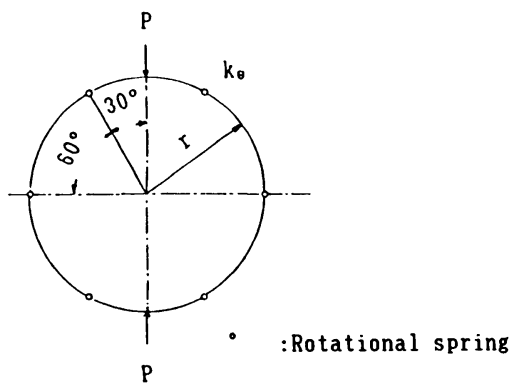

Fig. 6 Ring with rotational springs.

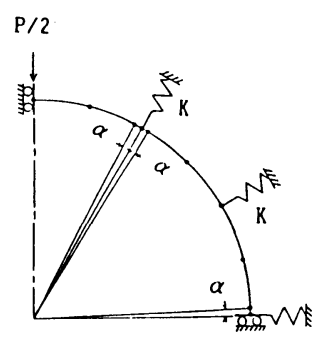

Fig. 7 Analytical model (Model 2).

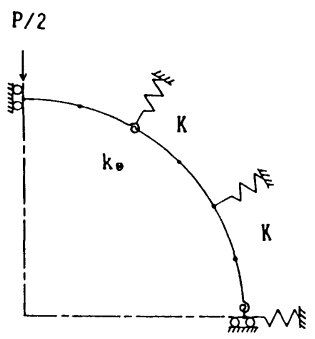

Fig. 8 Analytical model (Model 3).
発生前の状態を示す解析モデルである (Model 2).

Fig. 7 に示す $2 \alpha$ は鋼製りングのセグメント継手を評 価した切り欠き幅の中心角である. Model 2 ではセグメ ント継手を示す切り欠き部分の剛性を忠実に計算してい る.

Fig. 8 は同様な場合の解析モデル(Model 3)であって, セグメント継手位置の曲げ剖性の低下を回転ばねで評価 したものである。なおこの曲げモーメントに対する回転 ばね定数 $k_{\theta}$ は実験によって求めた。

（3）重ねリング構造と合成リング構造との組合せと 考えられる構造モデル (Model 4, Model 5)

モルタルリングにひびわれが発生するまでは合成リン グ構造として挙動している場合でも, 荷重の作用点の近 傍にひびわれが発生すると，ひびわれ位置付近は重ねリ ング構造として挙動し, 残余の部分は合成リング構造と して挙動していると考えられる。このような場合には, Model 1 とModel 2 または Model 1 と Model 3 を組み 合わせたモデルが考えられる.

Fig. 9 に示す Model 4 は Model 1 と Model 2 を組み 合わせた解析モデルである. すなわち荷重位置のモル夕 ルリングの節点をヒンジとするとともに，荷重方向から 中心角 $\theta_{0}$ までの範囲は重ねリング構造とし, 残余の範 囲は合成リング構造としている.さらに実際の数値計算 では Model 1 のプログラムをそのまま利用するため, 合成リング構造として挙動すると考えられる範井では, 合成断面の用性を鋼製リングの図心位置に集中させ，モ ルタルリングの図心位置の剛性を零とする.なお，七グ メント継手を想定した切り欠き部分の剛性低下は,

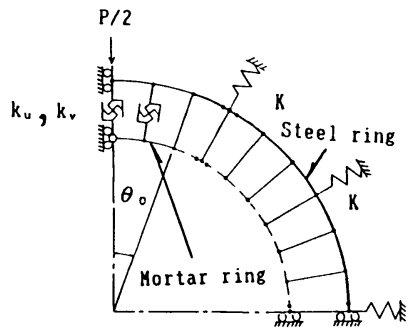

Fig. 9 Analytical model (Model 4).

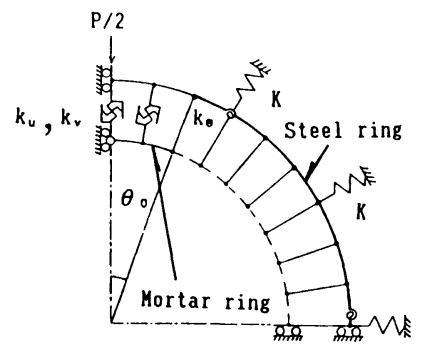

Fig. 10 Analytical model (Model 5). 
Model 2 における取扱いと同様である.

Model 4 と全く同様な考え方で, Model 1 と Model 3 を組み合わせて，七グメント継手位置の剛性低下を曲げ モーメントに対する回転ばねで評価した考え方が Model 5 で, Fig. 10 に示してある.なおこの場合の回 転ばね定数 $k_{\theta}$ も Model 2 と同様に実験によって求め た.

\section{4. 断面力の算定と分解}

（1）測定したひずみからの断面力算定法

ひずみ測定の断面は荷重方向から $10^{\circ}, 45^{\circ}$ および $80^{\circ}$ の計 12 断面であるが，モルタルリングの円周方向ひず みはこのほかに荷重方向とそれに直交する 4 断面が追加 されている.

リングの変形に際し平面保持の仮定が成り立つものと すれば，リングに生ずる円周方向のひずみ分布は双曲線 となる. したがって, モルタルリングについては測定さ れたひずみを最小二乗法で双曲線分布に近似させて断面 力を算定した. しかしながら鋼製リングではその図心半 径に比して板厚が小であるので, 近似的にひずみは直線 分布をするものと仮定して断面力を算定した.

\section{（2）合成リング構造モデルで理論的に求められた断 面力の分解}

Type 2〜Type 5 において合成リング構造と考えた部 分について理論的に求めた断面力 $(N, M)$ 一一軸力 $N$ は圧縮を正, 曲げモーメント $M$ はリングの内側に引張 を生ずるものを正とする一一実験値と比較する目的 で，鋼製リングの分担する断面力 $\left(N_{s}, M_{s}\right)$ とモルタ ルリングの分担する断面力 $\left(N_{m}, M_{m}\right)$ に分解した.

その方法を概説すれば次のごとくである.すでに述べ たように実験に用いたトンネル模型はその曲率半径に比 して断面の厚さが大であるので, モルタルに換算して T 型断面となる合成断面の応力度はFig. 11 に示すように 双曲線分布となり，その大きさは次式で示される.

$$
\sigma=-\frac{N}{A}+\frac{M}{A \rho_{0}}\left\{\frac{y}{\beta\left(\rho_{0}-y\right)}-1\right\} \text {. }
$$

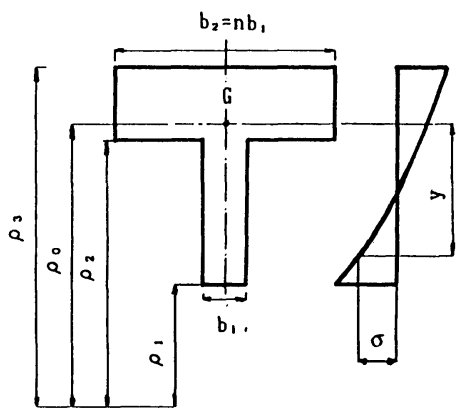

Fig. 11 Composite cross section and stress distribution.
ここに, $A$ は断面積， $\rho_{0}$ は合成断面の図心半径， $y$ は 図心位置（G）からリング内側に測った距離である。ま た $\beta$ は合成断面の形状寸法によって定まる定数で式

（2）で示され，Fig.11に記された $n$ はヤング係数比 である。

$$
\beta=\frac{\rho_{0}}{A}\left(b_{1} \log \frac{\rho_{2}}{\rho_{1}}+b_{2} \log \frac{\rho_{3}}{\rho_{2}}\right)-1
$$

ここに， $b_{1}, b_{2}$ はモルタルおよびモルタルに換算した 鋼製リングの厚さ， $\rho_{1}, \rho_{2}$ および $\rho_{3}$ は，それぞれモル夕 ルリングの内半径, 外半径および鋼製リングの外半径で ある

以上の結果をもととして，解析的に鋼製リングおよび モルタルリングの断面力を算定した.

\section{5. 実験結果と解析結果との比較}

モルタルで二次覆工を行ったトンネル模型の場合に は, $P$ が $500 \mathrm{kgf}(4.90 \mathrm{kN})$ から $800 \mathrm{kgf}(7.85 \mathrm{kN})$ 程度で荷重方向の近傍にひびわれを発生した。一方レジ ンモルタルを用いた場合には $2800 \mathrm{kgf}(27.46 \mathrm{kN})$ 程 度で同様な位置にひびわれが発生した。

したがって, 実験結果の整理にあたり, 荷重と直径変 化量との関係は実験値をひびわれ発生前後の理論值と比 較し, 荷重と曲げモーメントまたは軸力との関係は Table 1 に示すタイプごとに,ひびわれ発生前の代表値 として $P=500 \mathrm{kgf}(4.90 \mathrm{kN})$ に，またひびわれ発生後 については $P=3000 \mathrm{kgf}(29.42 \mathrm{kN})$ に換算して, そ の曲げモーメント図および軸力図を示した。

なお, Fig. 3 に示すジベルの寸法形状が直径変化量や 断面力に及ぼす影響は無視し得る程度であった。 以下各 タイプごとに実験結果と理論值の概要を示す.

\section{(1) Type 1}

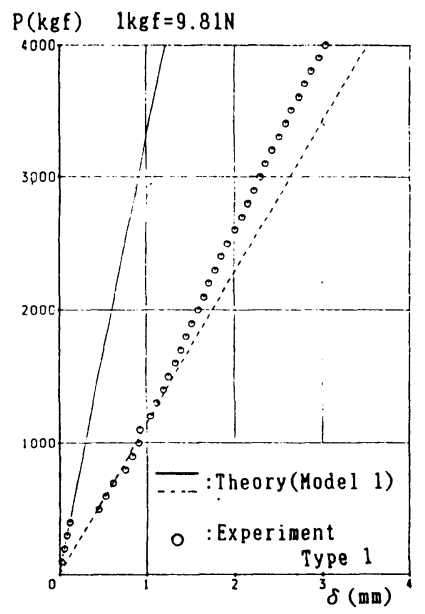

Fig. 12 Relationship between load and deformation in a direction to loading. 


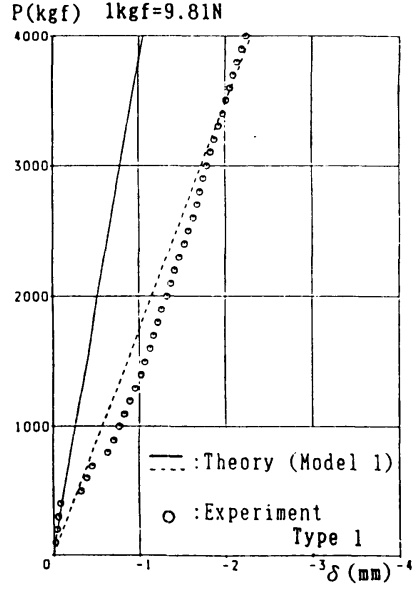

Fig.13 Relationship between load and deformation in a direction vertical to loading.

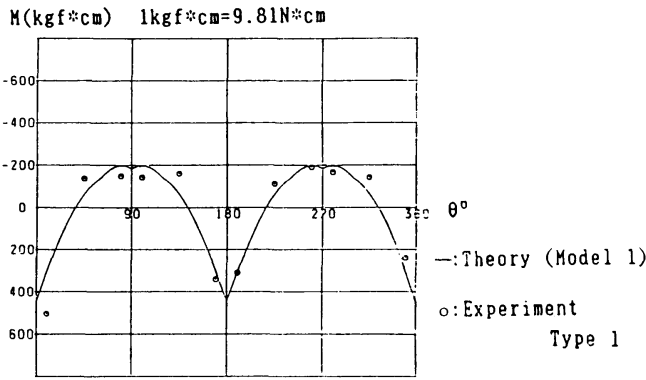

Fig. 14 Bending moment diagram (Steel ring) $P=500 \mathrm{kgf}$.

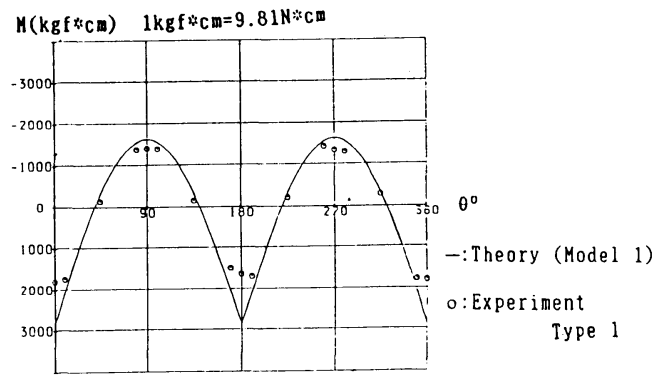

Fig. 15 Bending moment diagram (Mortar ring) $P=500 \mathrm{kgf}$.

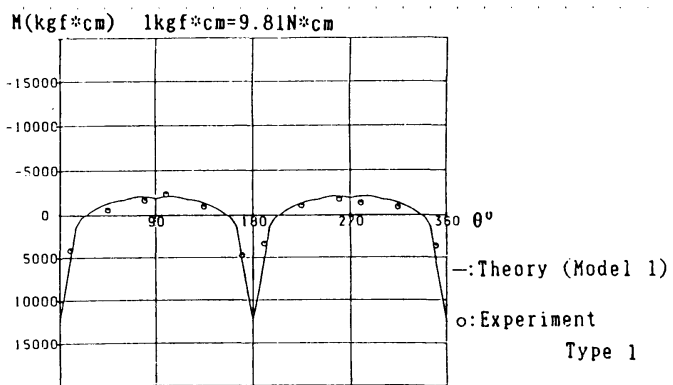

Fig. 16 Bending moment diagram (Steel ring) $P=3000 \mathrm{kgf}$.
Fig. 12, 13 は荷重と直径変化量との関係を示したも のであり，実線と破線はそれぞれひびわれ発生前後の Model 1 による理論値である.

Fig. 14〜17はひびわれ発生前後の鋼製リングおよび モルタルリングの分担する曲げモーメント図であり, 実 線は Model 1 による理論値である.

\section{(2) Type 2}

この場合は Type 1 とほぼ同様な傾向を示したので, Fig. 18，19にひびわれ発生後の曲げモーメント図のみ を示した。図中の実線は解析 Model 1 による理論值で ある. Fig. 18 において $\theta$ が $90^{\circ}$ および $270^{\circ}$ 付近で曲げ モ一メント図が波形を示しているのは，弾性支承の影響 である.

(3) Type 3

Fig. 20，21 はひびわれ発生後の曲げモーメント図で

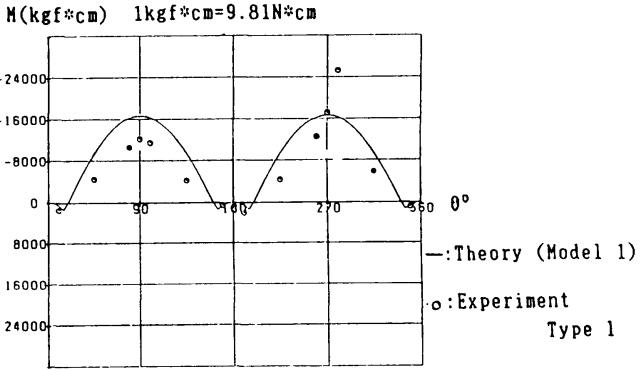

Fig. 17 Bending moment diagram (Mortar ring) $P=3000 \mathrm{kgf}$

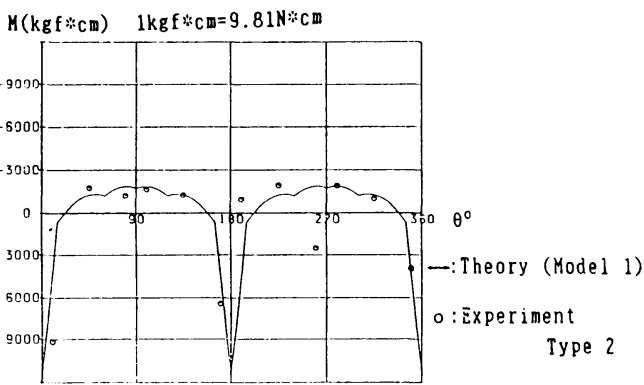

Fig. 18 Bending moment diagram (Steel ring) $P=3000 \mathrm{kgf}$.

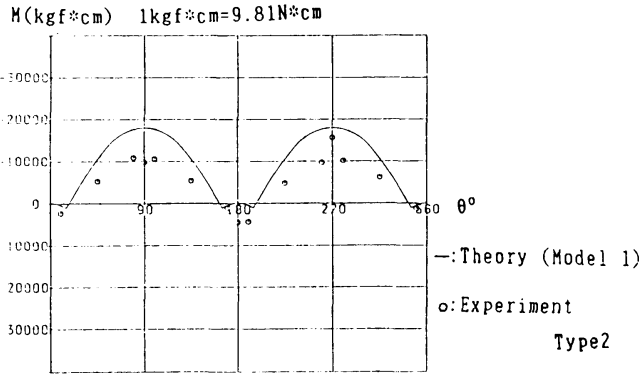

Fig. 19 Bending moment diagram (Mortar ring) $P=3000 \mathrm{kgf}$. 
あり，Fig. 22 は軸力図である. 実線は Model 4 におい て $\theta_{0}=45^{\circ}$ とした理論值であり，破線は Model 5 におい て $\theta_{0}=45^{\circ}$ とした理論值であるが, 両者の相違は無視し 得る程度である.

通常の荷重状態では $\theta_{0}=45^{\circ}$ 付近で曲げモーメントの 符号が変化する.したがって, 正の曲げを受ける範囲は 重ねリング構造とし, 負の曲げを受ける範井は合成りン グ構造と考えたものである.

解析モデルとして, Model 4 を用いるか, Model 5 を 用いるか，すなわちセグメント継手を断面の曲げ䣓性の 低下と考えるか, 曲げモーメントに対する回転ばねに置 換するかはトンネルの挙動に基本的な相違を与えないこ とが明らかとなった。

\section{(4) Type 4}

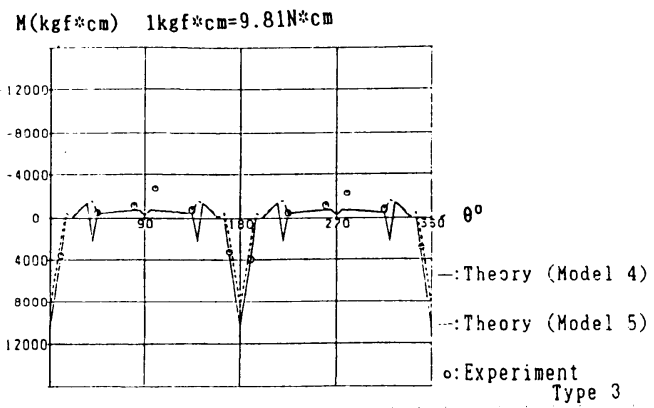

Fig. 20 Bending moment diagram (Steel ring) $P=3000 \mathrm{kgf}$.

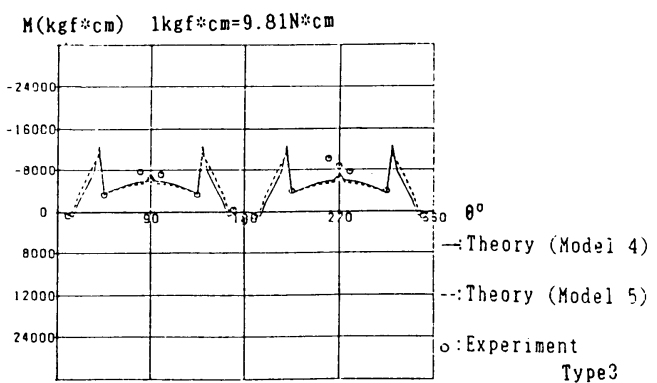

Fig. 21 Bending moment diagram (Mortar ring) $P=3000 \mathrm{kgf}$.

$N(\mathrm{kgf}) \quad 1 \mathrm{kgf}=9.81 \mathrm{~N}$

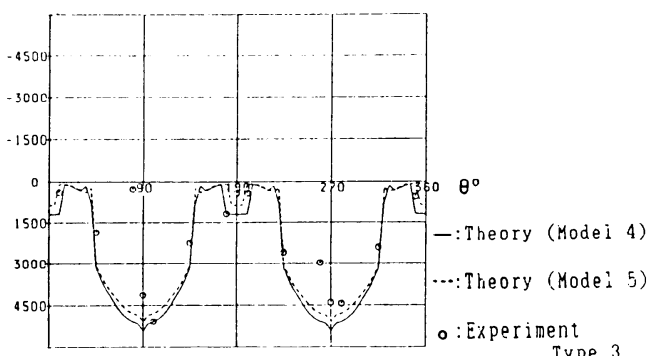

Type 3

Fig. 22 Axial force diagram (mortar ring) $P=3000 \mathrm{kgf}$.
Fig. 23，24 はひびわれ発生後の曲げモーメント図で あり，実線は Model 4 において $\theta_{0}=20^{\circ}$ とした理論值で あり，破線は Model 5 において $\theta_{0}=20^{\circ}$ とした理論値で ある.

なお，ひびわれ発生前の模型トンネルの挙動は Model 2 または Model 3 による理論值が実験結果をよ く説明しているが，図面は割愛する.

\section{(5) Type 5}

Fig. 25，26 は荷重と直径変化量との関係を示したも

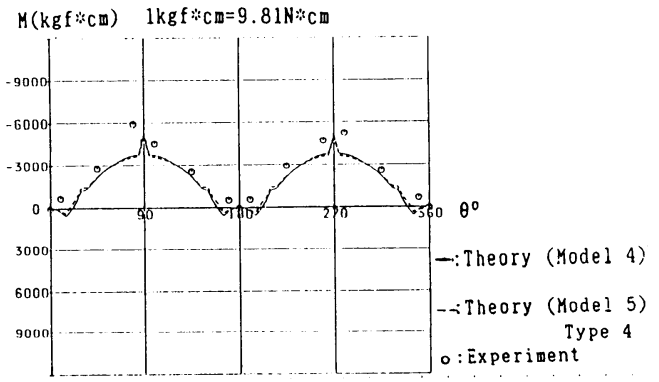

Fig. 23 Bending moment diagram (Steel ring) $P=3000 \mathrm{kgf}$.

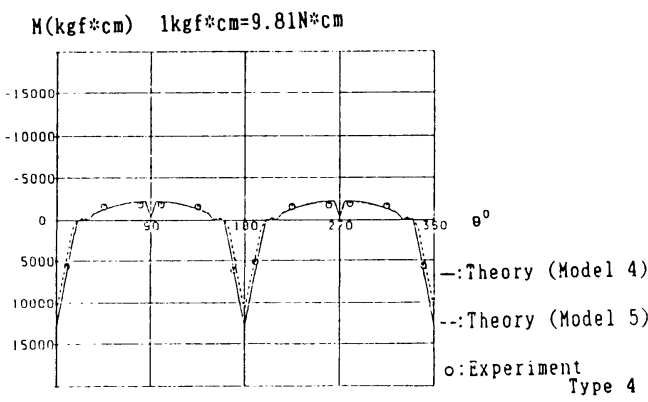

Fig. 24 Bending moment diagram (Resin mortar ring) $P=3000 \mathrm{kgf}$.

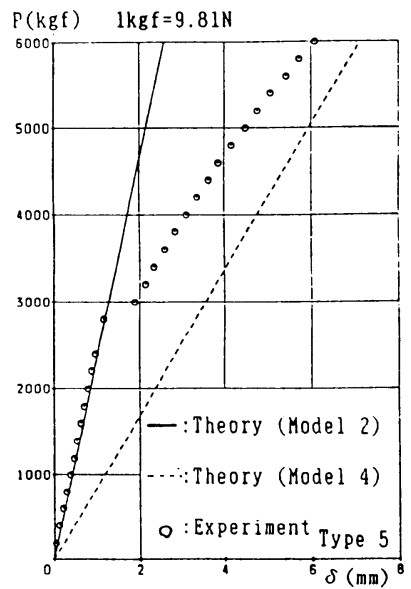

Fig. 25 Relationship between load and deformation in a direction of loading. 
のである.ひびわれ発生前の理論値は Model 2 によっ たものであり, ひびわれ発生後の理論值は Model 4 に おいて $\theta_{0}=20^{\circ}$ としたものである.

Fig. 27，28 はひびわれ発生前の曲げモーメントの一 例であり，実線は Model 2 による理論值である.

Fig. 29，30 はひびわれ発生後の曲げモーメント図で あり Fig. 31 はひびわれ発生後の軸力図である. 図中実 線は Model 4 において $\theta_{0}=20^{\circ}$ とした理論値であり, 破 線は Model 5 において $\theta_{0}=20^{\circ}$ とした理論値である. 両

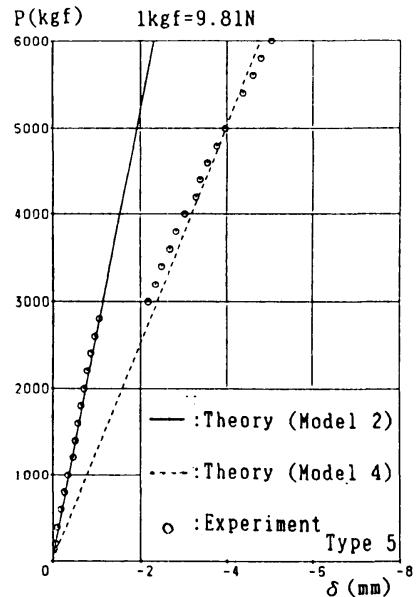

Fig. 26 Relationship between load and deformation in a direction vertical to loading.

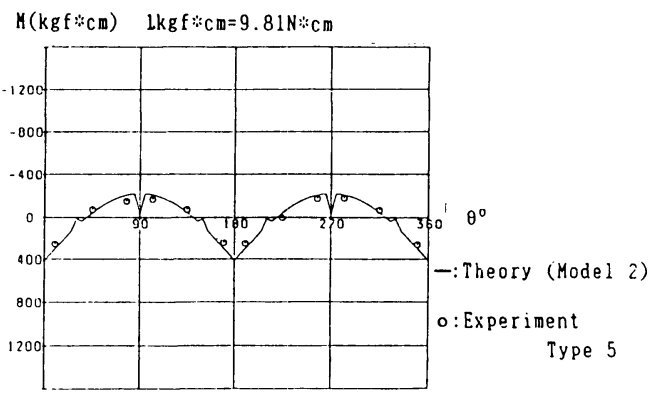

Fig. 27 Bending moment diagram (Steel ring) $P=500 \mathrm{kgf}$.

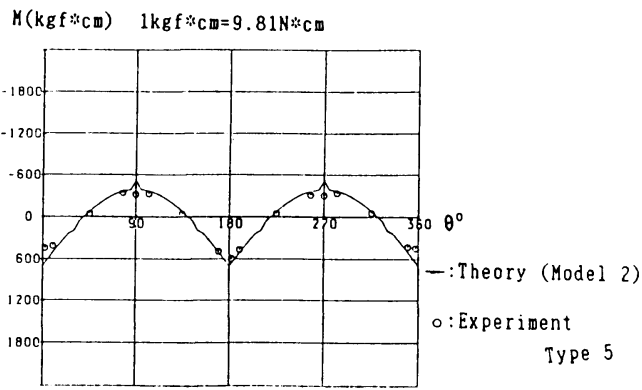

Fig. 28 Bending moment diagram (Resin mortar ring) $P=500 \mathrm{kgf}$
者による値の違いは無視し得る程度である.

$\theta_{0}=20^{\circ}$ としたのは，ひびわれ発生位置から最寄のジ ベル位置までの中心角が $20^{\circ}$ であるためである.

（6）まと め

以上 5 つのタイプについて，その実験結果と解析結果 とを比較したが，両者はよい符合を示した.

直径変化量, 両リングの曲げモーメント分布および軸 力分布などの実験結果と解析結果を総合的に比較して特 徵的な点を列挙すれば次のごとくである.

i）二次覆工材としてモルタルを使用し，ジベルを設 けない場合か，非常にわずかしか設けない場合には 鋼製リングとモルタルリングとは重ねリング構造と して挙動する。

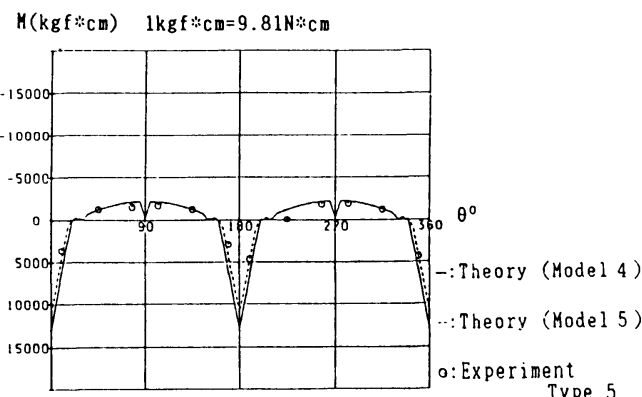

Fig. 29 Bending moment diagram (Steel ring) $P=3000 \mathrm{kgf}$.

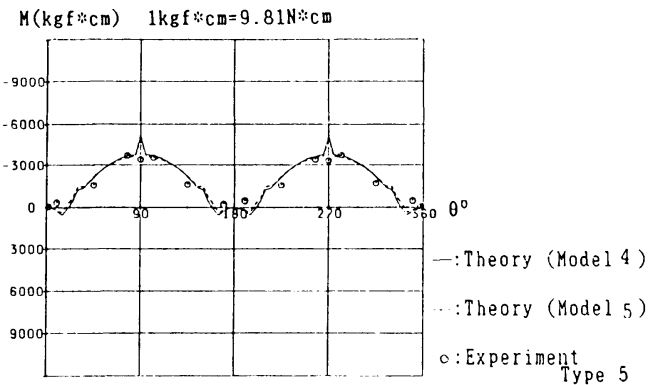

Fig. 30 Bending moment diagram (Resin mortar ring) $P=3000 \mathrm{kgf}$.

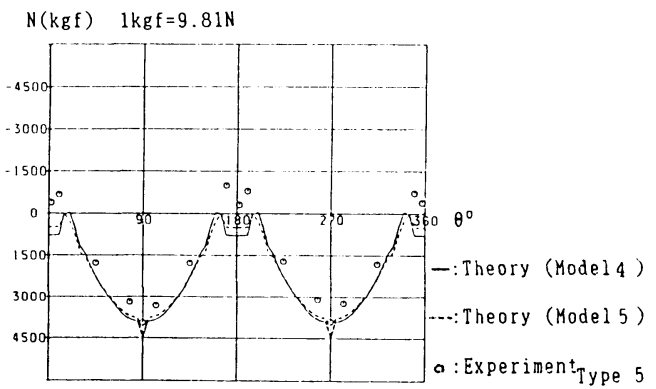

Fig. 31 Axial force diagram (Resin mortar ring) $P=3000 \mathrm{kgf}$. 
ii）二次覆工材としてモルタルを使用し，ジベルを密 に設けた場合には，䤡製リングとモルタルリングに 生ずる曲げモーメントが正の範囲では重ねリング構 造として, 負の範囲では合成リング構造として挙動 する.

iii）二次覆工材としてレジンモルタルを用いた場合に は, ジベルの有無にかかわらず,ひびわれ発生前に おいては合成リング構造として挙動し，ひびわれ発 生後はひびわれ位置の近傍のみ重ねリング構造とし て，残余の部分は合成リング構造として挙動する.

以上に提示した解析モデルの基本的な考え方は, 現実 のトンネルの挙動を明らかにするものであると考えてい る.

\section{6. 実験結果のシールドトンネル設計への適用}

以上にモルタルで二次覆工された模型トンネルの1リ ングを対象とした実験結果と，その結果を説明する解析 モデルについて述べた。この結果は，七グメントリング をいも継ぎに組み立てる場合には，ただちに適用できる ことを示している.しかしながらわが国のシールドトン ネルでは，七グメントリングを千鳥組にするのが一般的 である.したがってセグメントリングを千鳥組した場合 に，今回報告した方法をそのまま適用することはできな W.

著者らは,千鳥組されたセグメントリングに関しては, すでにその耐荷機構を明らかにしている ${ }^{17)}$. その中で, もし曲げ㴊性の有効率 $\eta$ と曲げモーメントの割増率 が合理的に推定できるならば，いわゆる慣用計算法は簡 単で有効な方法であると指摘するとともに，そこで示さ

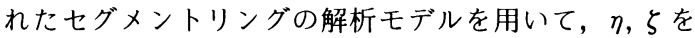
合理的に推定する方法についても論述している. した がってこの方法によってリングの曲げ剛性の有効率 $\eta$ を推定すれば，千鳥組されたセグメントリングの変形性 能を 1 リングに置き換えて評価することができることに なり，今回報告した方法がこのような場合に適用可能で あることを示している. 以下にその手順を簡単に示す.

まず設計の対象となる地盤条件のもとで, 千鳥組され たセグメントリングの鉛直方向直径変形量 $\delta_{v 0}$ を著者ら の方法で求める. 次に $\eta E I$ なる曲げ用性一様なリング の鉛直方向直径変形量 $\delta_{v}$ を $\eta$ パラメーターとして, 同様な方法で計算すれば, Fig. 32 に示す曲線を得る.

この曲線と $\delta_{v}=\delta_{v 0}$ なる直線の交点の值として $\eta$ を求 めれば，二次覆工で補強されて千鳥組されたシールドト ンネルの挙動は Fig. 33 に示すように, $\eta E I$ なる剛性を もつセグメントリングと $(E I)_{c}$ なる剛性をもつ二次覆 工に 1 リングを対象とした本研究の結果を適用すればよ い. $\eta$ の値として, 水平方向直径変形量から求められる

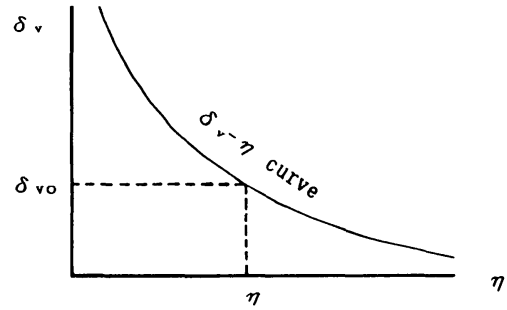

Fig. 32 Relationship between diameter change and effectivety of flexural rigidity.

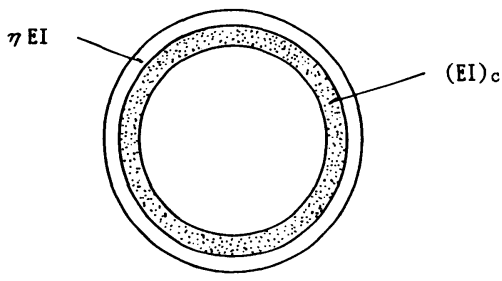

Fig. 33 Analytical model.

$\eta$ との平均值をとれば，なお望ましい曲げ剛性の有効率 が得られるであろう。

\section{7. 結 論}

著者らは二次覆工が耐荷能力を発揮できるようになっ た後に作用する荷重に対して，模型トンネルを用いてそ の挙動を明らかにし，これを説明する解析モデルを提案 するとともに，実際のシールドトンネルへの適用性につ いても論述した．数例ではあるが，すでにこの方法は実 際のトンネルの試算にも用いられている。

なおより現実を正確に把握するために，現在干鳥組さ れたリングに二次覆工した模型トンネルについても実験 ならびに解析を行っている。

最後に，本論文をまとめるにあたって，その一部を修 論や卒論で助力願った多くの卒業生に感謝する次第で す.

\section{参 考 文 献}

1）土木学会・日本下水道協会：シールド工事用標準セグメ ント, p. 50, 1982.

2）土木学会：関門墜道, pp. 41 43，1949.

3）建設省・日本道路公団：関門トンネル工事誌，p. 103， 1960.

4) K. Széchy : The Art of Tunnelling, pp. 451 454, 1973.

5) 土木学会：トンネル標準示方書 (シールド編), p. 27, pp. 75 76, 1986.

6）渡辺・小山ほか：円環二層構造の力学的挙動に関する実 験その 1 , 土木学会講演概要集, pp. 399 400, 1982.

7）藤森・半谷ほか：同上その 2, 土木学会講演概要集, pp. $401 \sim 402,1982$.

8）半谷・小山ほか：セグメントと二次覆工からなるトンネ 
ル覆工の力学的挙動に関する実験その 1 , 土木学会講演 概要集, pp. $171 \sim 172,1983$.

9) 半谷・小山ほか：同上その 2, 土木学会講演概要集, pp. $173 \sim 174,1983$.

10）半谷・飯田ほか：セグメントと二次覆工の接合面に設け る凹凸の破壊強度について, 土木学会講演概要集, pp. $605 \sim 606,1984$.

11）村上・小泉ほか：二次覆工で補強されたシールドトンネ ルの挙動について, 土木学会講演概要集, pp. 395 396, 1982.

12）村上.小泉ほか：同上, 土木学会講演概要集, pp. 169 $170,1983$.
13）村上·小泉：同上, 土木学会講演概要集, pp. 623 624, 1984.

14）村上・小泉ほか：同上, 土木学会講演概要集, pp. 349 350, 1985.

15）村上・小泉ほか：同上, 土木学会講演概要集, pp. 845 846, 1986.

16）半谷哲夫：二次覆工を有するシールドトンネル覆工の力 学的特性に関する研究，鉄道技術研究所報告, No. 1303, 1985.

17）村上博智・小泉 淳：セグメントリングの㶦荷機構につ いて，土木学会論文報告集，第 272 号，1978.

（1987.2.23 - 受付） 